\title{
Pelaksanaan Prinsip-Prinsip Manajemen Keuangan Dalam Tata Kelola Keuangan Alokasi Dana Desa Di Desa Karumbu Kecamatan Langgudu Kabupaten Bima
}

\author{
Hartoyo \\ hartoyobima321@gmail.com
}

\begin{abstract}
Abstrak. Pengelolaan keuangan desa yang partisipatif dalam penggunaan dana Alokasi Dana Desa,berarti sejak tahap perencanaan,pelaksanaan,penatausahaan,pelapora dan pertanggugjawaban wajib melibatkan masyarakat, para pemangku kepentingan di desa serta masyarakat luas, utamanya kelompok marjinal sebagai penerima manfaat dari program/kegiatan pembangunan di desa. Pelitian ini dirancang sebagai penelitian kualitatif dan dilakukan kepada staf pemerintah desa, pengelola Alokasi Dana Desa, pengurus lembaga desa, masyarakat, dan kepala desa yang dijadikan sumber data. Sumber data ditentukan sebanyak 14 orang dari subyek penelitian. Instrumen pengumpul data adalah wawancara, observasi, dan pencatatan dokumentasi. Data diolah dimulai dari reduksi data, penyajian data, dan pengambilan kesimpulan dan verifikasi. Hasil penelitian yakni: pertama, berdasarkan keempat sub fokus kaitan dengan prinsip partisipatif dalam pengelolaan keuangan Alokasi Dana Desa, hasilnya telah sesuai dengan amanah Peraturan Menteri Dalam Negeri Republik Indonesia Nomor 113 Tahun 2014 Tentang Pengelolaan Keuangan Desa dan Undang-Undang RI Nomor 6 Tahun 2014 tentang Desa. Kedua, berdasarkan keempat indikator kaitan dengan fokus prinsip transparansi dalam penggunaan Alokasi Dana Desa, hasilnya telah sesuai dengan amanah Peraturan Menteri Dalam Negeri Republik Indonesia Nomor 113 Tahun 2014 Tentang Pengelolaan Keuangan Desa dan Undang-Undang RI Nomor 6 Tahun 2014 tentang Desa. Beberapa saran diajukan sebagai berikut: pertama, walaupun penerapan prinsip partisipatif dalam pengelolaan dan penggunaan Alokasi Dana Desa, pelaksanaannya sudah berjalan sesuai dengan aturan penggunaan Alokasi Dana Desa, akan tetapi perlu terus ditingkatkan di masa-masa yang akan datang, minimal dipertahankan walaupun mempertahankan dianggap suatu kemunduran bahkan dinilai gagal karena waktu telah berubah. Kedua, walaupun penerapan prinsip transparansi dalam penggunaan Alokasi Dana Desa, pelaksanaannya sudah berjalan sesuai dengan aturan penggunaan Alokasi Dana Desa, akan tetapi perlu terus ditingkatkan di masa-masa yang akan datang, minimal dipertahankan, walaupun mempertahankan dianggap suatu kemunduran bahkan dinilai gagal karena waktu telah berubah.
\end{abstract}

Kata kunci: Prinsip, Manajemen Keuangan, Tata Kelola, dan Alokasi Dana Desa

\section{PENDAHULUAN}

Melalui Alokasi Dana Desa (ADD), desa berpeluang untuk mengelola pembangunan, pemerintahan dan sosial kemasyarakatan desa secara otonom. Alokasi Dana Desa adalah dana yang diberikan kepada desa yang berasal dari dana perimbangan keuangan pemerintah pusat dan daerah yang diterima oleh kabupaten.

Pelaksanaan Alokasi Dana Desa ini dilakukan dengan melalui fisik dan non fisik yang berhubungan dengan indikator perkembangan desa. Indikator perkembangan desa meliputi tingkat pendidikan, tingkat pendapatan, tingkat kesehatan. Dengan pemberian Alokasi Dana Desa pembangunan fisik selama ini dianggap relatif cukup memenuhi prasarana dan sarana desa, namun demikian desa-desa masih jauh dari keberhasilan pembangunan fisik.

Berdasarkan Permendagri No 37 Tahun 2007 tentang Pedoman Pengelolaan Keuangan Desa, bahwa pengelolaan Alokasi Dana Desa merupakan bagian yang tidak terpisahkan dari pengelolaan keuangan desa. Seluruh kegiatan yang didanai Alokasi Dana Desa direncanakan, dilaksanakan dan dievaluasi secara terbuka dengan melibatkan seluruh unsur masyarakat di Desa. Seluruh kegiatan harus dapat dipertanggungjawabkan 
secara administrasi, teknis dan hukum. Alokasi Dana Desa dilaksanakan dengan menggunakan prinsip hemat, terarah dan terkendali.

Pengelolaan Alokasi Dana Desa merupakan satu kesatuan dengan pengelolaan keuangan desa. Rumus yang dipergunakan dalam Alokasi Dana Desa adalah: pertama, azas merata adalah besarnya bagian Alokasi Dana Desa yang sama untuk setiap desa, yang selanjutnya disebut Alokasi Dana Desa Minimal (ADDM); kedua, azas adil adalah besarnya bagian Alokasi Dana Desa berdasarkan Nilai Bobot Desa (BDx) yang dihitung dengan rumus dan variabel tertentu (misalnya kemiskinan, keterjangkauan, pendidikan dasar, kesehatan, dan lain-lain), selanjutnya disebut Alokasi Dana Desa Proporsional (ADDP); dan ketiga, besarnya prosentase perbandingan antara azas merata dan adil sebagaimana dimaksud pada ayat (2) di atas, adalah besarnya ADDM adalah $60 \%$ (enampuluh persen) dari jumlah ADD dan besarnya ADDP adalah 40\% (empatpuluh persen) dari jumlah ADD (Santosa (2008: 128).

Dalam mengelola atau manajemen keuangan desa, termasuk Alokasi Dana Desa (ADD), maka ada sejumlah prinsip pengelolaan Alokasi Dana Desa yang harus dipatuhi dan ditaati, yaitu prinsip transparansi, prinsip akuntabilitas, dan prinsip partisipatif. Di samping ada juga prinsip responsif, dan prinsip tertib dan disiplin anggaran.

Penggunaan anggaran dan keuangan, dari sumber manapun, apakah itu dari pemerintah, Alokasi Dana Desa misal, ataupun dari masyarakat perlu didasarkan prinsip-prinsip umum pengelolaan keuangan sebagai berikut: pertama, hemat, tidak mewah, efisien dan sesuai dengan kebutuhan teknis yang disyaratkan; kedua, terarah dan terkendali sesuai dengan rencana, program/kegiatan; ketiga, terbuka dan transparan, dalam pengertian dari dan untuk apa keuangan lembaga tersebut perlu dicatat dan dipertanggung jawabkan serta disertai bukti penggunaannya; dan keempat, sedapat mungkin menggunakan kemampuan/hasil produksi dalam negeri sejauh hal ini dimungkinkan (Sumpeno Wahjudin, 2011: 192).

Kaitan dengan pentingnya pelaksanaan prinsip-prinsip manajemen keuangan Alokasi Dana Desa, maka penulis akan mengkaji dengan mengetengahkan judul: "Pelaksanaan Prinsip-prinsip Manajemen Keuangan dalam Tata Kelola Keuangan Alokasi Dana Desa di Desa Karumbu Kecamatan Langgudu Kabupaten Bima." METODE PENELITIAN

Rancangan atau desain penelitian adalah semua proses yang diperlukan dalam perencanaan dan pelaksanaan penelitian. Desain penelitian adalah semua proses yang diperlukan dalam perencanaan dan pelaksanaan penelitian. Desain yang digunakan dalam penelitian ini adalah penelitian deskriptif, desain ini digunakan untuk mendapatkan deskriptif tentang suatu kenyataan yaitu tentang persepsi siswa tentang akhlak dan sikapnya.

Rancangan atau desain penelitian dalam arti sempit dimaknai sebagai suatu proses pengumpulan dan analisis data penelitian. Dalam arti luas rancangan penelitian meliputi proses perencanaan dan pelaksanaan penelitian. Dalam rancangan perencanaan dimulai dengan mengadakan observasi dan evaluasi terhadap penelitian yang sudah dikerjakan dan diketahui, sampai pada penetapan kerangka konsep dan hipotesis penelitian yang perlu pembuktian lebih lanjut.

Rancangan pelaksanaan penelitian meliputi proses membuat percobaan ataupun pengamatan serta memilih pengukuran variabel, prosedur dan teknik sampling, instrumen, pengumpulan data, analisis data yang terkumpul, dan pelaporan hasil penelitian. Tujuan rancangan penelitian adalah untuk memberikan suatu rencana untuk menjawab pertanyaan-pertanyaan penelitian.

Penelitian ini dilakukan dengan metode studi kasus (case study) yakni, pengamatan secara detail terhadap obyek atau orang, baik pada satu titik waktu atau beberapa titik waktu. Penelitian ini melibatkan data kualitatif, serta menggunakan logic analytic menurut Smith (2003) dalam Simanjuntak dan 
Januarsi (2011). Penelitian dilakukan melalui pengamatan langsung dilapangan yakni desa yang telah dipilih oleh peneliti atau dengan cara purposive sampling yakni sampel yang telah ditetapkan oleh peneliti dengan alasan dan tujuan khusus. Pengamatan dilakukan melalui keterlibatan secara langsung terhadap semua kegiatan yang dilakukan oleh obyek penelitian dalam waktu tertentu sehingga diperoleh gambaran utuh tentang pengelolaan keuangan desa, selain itu juga dilakukan wawancara secara tidak terstruktur selama proses pengamatan langsung tersebut.

Sebagai salah satu metode penelitian, studi kasus digunakan dalam banyak situasi untuk memberikan kontribusi terhadap ilmu pengetahuan, bagi individu, kelompok, organisasi, sosial dan politik, serta fenomena yang berhubungan satu dengan lainnya. Studi kasus banyak diterapkan pada penelitianpenelitian psikologi, ilmu politik, pekerja sosial, bisnis dan perencanaan sosial. Namun, pendekatan studi kasus tidak familiar pada penelitian-penelitian ilmu akuntansi atau ilmu ekonomi lainnya, keunggulan pendekatan studi kasus adalah peneliti mampu memenuhi semangat keingintahuan dalam memahami fenomena sosial yang terjadi dalam masyarakat, pendekatan ini akan memberikan pemahaman yang holistik terhadap peneliti akan arti dari karakteristik berbagai kejadian dalam kehidupan, seperti siklus kehidupan, organisasi, proses managerial, perubahan lingkungan, hubungan internasional dan transformasi industri (Yin 2003).

Adapun desain penelitian yang penulis rancang dilihat pada skema berikut:

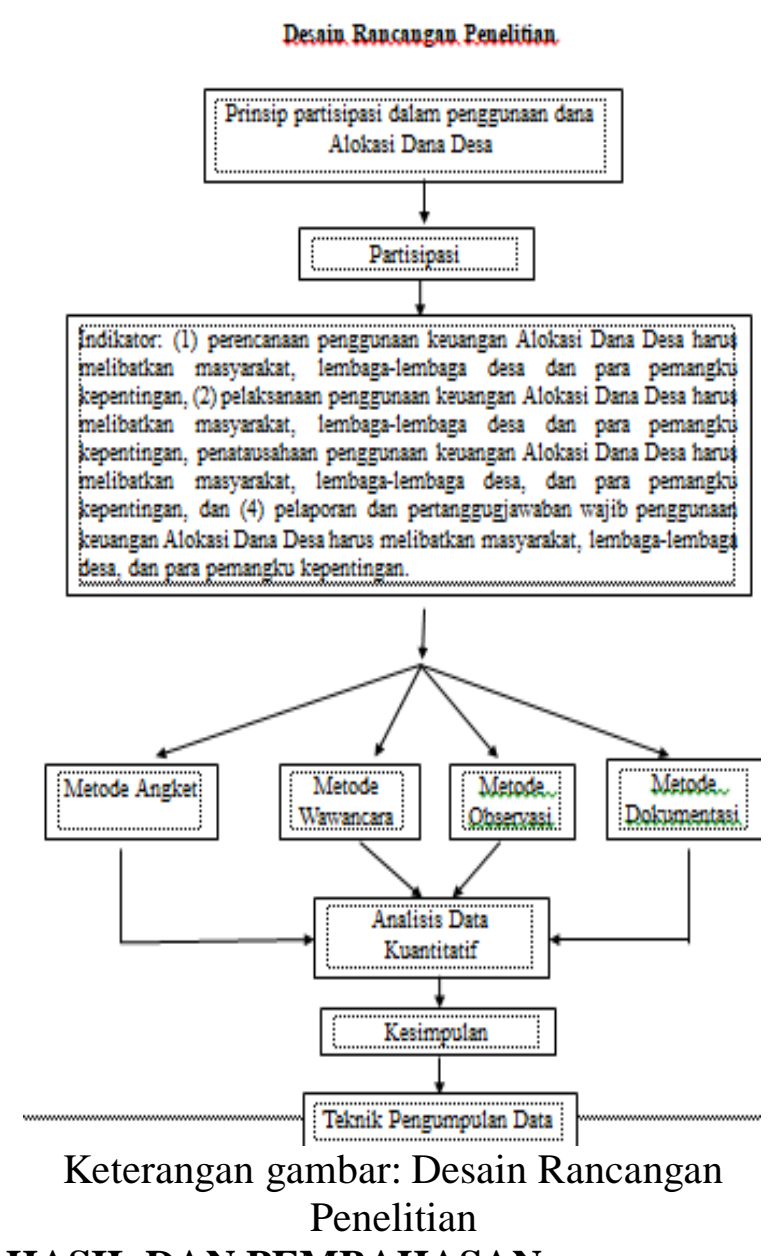

\section{HASIL DAN PEMBAHASAN}

\section{A. Uraian Data Penelitian}

Subyek penelitian atau sumber data dalam penelitian adalah Ketua dan Pengurus

BPD, Ketua LPMD, staf desa, tokoh masyarakat, dan warga di Desa Karumbu Kecamatan Langgudu Kabupaten Bima.

Adapun nama-nama subyek penelitian terlihat pada tabel berikut ini.

\begin{tabular}{|c|l|l|}
\hline No. & \multicolumn{1}{|c|}{ Informan } & \multicolumn{1}{|c|}{ Keterangan } \\
\hline 1 & Drs. Mukhtar & Pengurus BPD \\
2 & Sulaiman & Warga \\
3 & Drs. H. Taje Palna & Ketua LPMD \\
4 & Abdul Farid & Kepala Dusun \\
5 & Ishaka & Warga \\
6 & Hamdun & Kasi Ekonomi/Pembangunan \\
7 & Yusran M. Sidik & Warga \\
8 & Sri Winarti & Kabid Umum dan Aset \\
9 & Ny. Siti Mariamah & Tokoh masyarakat \\
10 & H. Muhammad Arif & Warga \\
11 & Abdul Haris & Kabid Perencanaan dan Pelaporan \\
12 & Muhammad Saleh & Tokoh masyarakat \\
13 & Rahmi M. Ali & Warga \\
14 & Rusdin & Warga \\
15 & Syahrul, S.Pd & Tokoh masyarakat \\
16 & Muhammad Abbas & Warga \\
17 & Karim & Warga \\
18 & Wahyudin. S.Sos & Sekretaris Desa \\
19 & Abdullah Ahmad & Warga \\
20 & Aminah & Warga \\
21 & Abdul Malik Ahmad & Warga \\
22 & Burhan & Warga \\
23 & Mukhlis & Kaur Keuangan \\
\hline
\end{tabular}

Sumber: Kantor Desa Karumbu Kecamatan Langgudu Kabupaten Bima, 2017 


\section{B. Analisis Data Penelitian}

Sesuai dengan masalah yang diajukan pada Bab I, maka dalam penelitian ini rumusan masalah yang akan dianalisis atau dibahas yaitu berkaitan dengan pelaksanaan prinsip-prinsip manajemen keuangan dalam tata kelola keuangan Alokasi Dana Desa di Desa Karumbu Kecamatan Langgudu Kabupaten Bima.

Terdapat 4 (empat) konsep/variabel yang akan diuraikan pada bagian ini, yakni pertama, proses untuk mendapatkan Alokasi Dana Desa; kedua, darimanakah sumbersumber Alokasi Dana Desa; ketiga, proses penggunaan Alokasi Dana Desa; dan keempat, dipakai untuk apa saja Alokasi Dana Desa tersebut.

Untuk lebih jelas bagaimana tanggapan informan terhadap permasalahan yang diajukan dalam penelitian ini akan diuraikan satu per satu sebagai berikut.

Terdapat 3 (tiga) tahapan dalam analisis data kualitatif ini, yang dimulai dengan reduksi data, penyajian data, dan pengambilan kesimpulan dan verifikasi, dan untuk lebih jelasnya akan diurakan sebagai berikut.

\section{Reduksi Data}

Pada tahap ini, peneliti melakukan seleksi, pemilihan, penyederhanaan dan pengabstrakkan dengan cara koding atas datadata yang terkumpul. Dalam penelitian ini terdapat 2 (dua) fokus yang akan diuji kaitan dengan penerapan prinsip-prinsip pengelolaan keuangan Alokasi Dana Desa di Desa Karumbu Kecamatan Langgudu Kabupaten Bima, yaitu: pertama, prinsip partisipatif dalam pengelolaan keuangan Alokasi Dana Desa; dan kedua, prinsip transparansi pengelolaan keuangan Alokasi Dana Desa.

Bagaimana realisasi terhadap dua fokus tentang penerapan prinsip-prinsip pengelolaan keuangan Alokasi Dana Desa di Desa Karumbu Kecamatan Langgudu Kabupaten Bima, akan terlihat dengan jelas sebagaimana sajian kutipan hasil wawancara berikut.

\section{Penerapan prinsip partisipatif dalam penggunaan Alokasi Dana Desa}

Kaitan dengan fokus prinsip partisipatif dalam pengelolaan keuangan
Alokasi Dana Desa, maka terdapat 4 (empat) indikatornya, yaitu: pertama, perencanaan penggunaan keuangan Alokasi Dana Desa harus melibatkan masyarakat, lembaga-lembaga desa dan para pemangku kepentingan; kedua, pelaksanaan penggunaan keuangan Alokasi Dana Desa harus melibatkan masyarakat, lembaga-lembaga desa dan para pemangku kepentingan; ketiga, penatausahaan penggunaan keuangan Alokasi Dana Desa harus melibatkan masyarakat, lembaga-lembaga desa, dan para pemangku kepentingan; dan keempat, pelaporan dan pertanggugjawaban wajib penggunaan keuangan Alokasi Dana Desa harus melibatkan masyarakat, lembagalembaga desa, dan para pemangku kepentingan.

Untuk mengetahui bagaimana penerapan prinsip partisipatif dalam penggunaan Alokasi Dana Desa di Desa Karumbu Kecamatan Langgudu Kabupaten Bima, maka akan terlihat sebagaimana sajian kutipan hasil wawancara secara berturut-turut berikut ini.

1) Perencanaan penggunaan keuangan Alokasi Dana Desa harus melibatkan masyarakat, lembaga-lembaga desa dan para pemangku kepentingan

Indikator pertama dari fokus prinsip partisipatif dalam pengelolaan keuangan Alokasi Dana Desa, yaitu: perencanaan penggunaan keuangan Alokasi Dana Desa harus melibatkan masyarakat, lembagalembaga desa dan para pemangku kepentingan.

Secara umum, pengertian perencanaan keuangan adalah kegiatan untuk memperkirakan pendapatan dan belanja untuk kurun waktu tertentu di masa yang akan datang. Dalam kaitannya dengan pengelolaan keuangan desa, perencanaan dimaksud adalah proses penyusunan APBDes.

Pengelolaan keuangan desa sebagai rangkaian kegiatan, diawali dengan kegiatan perencanaan, yaitu penyusunan APBDesa. Dengan demikian, penting untuk memahami secara tepat berbagai aspek APBDesa: fungsi, 
ketentuan, struktur, sampai mekanisme penyusunannya.

Untuk mengetahui bagaimana perencanaan penggunaan keuangan Alokasi Dana Desa harus melibatkan masyarakat, lembaga-lembaga desa dan para pemangku kepentingan di Desa Karumbu Kecamatan Langgudu Kabupaten Bima, akan terlihat sebagaimana sajian hasil wawancara berikut.

Hasil wawancara dengan salah seorang pengurus BPD Desa Karumbu Kecamatan Langgudu Kabupaten Bima yang bernama Bapak Drs. Mukhtar sebagai berikut:

"Kami selaku anggota BPD menjadi mitra yang baik bagi pengelola keuangan Alokasi Dana Desa. Lalu, kaitan dengan pengelolaan keuangan Alokasi Dana Desa, sudah ada prosedur atau tata cara penggunaannya. Dan itu sangat jelas menurut saya. Jika tidak mengikuti prosedur yang benar, pemerintah dan masyarakat bisa menuntutnya. Nah, di desa kami ini cukup baik perencanaan penggunaan keuangan Alokasi Dana Desa. Kenapa? Karena telah melibatkan masyarakat, lembaga-lembaga desa dan para pemangku kepentingan desa. Buktinya, tidak ada persoalan besar. Ya, biasa kalau hanya saling curiga. Tapi, tidak lebih dari itu. Ya, untuk sementara ya. Saya tidak tahu ke depannya" (Hasil Wawancara, Juni 2017)

Hasil wawancara dengan salah seorang warga yang bernama Bapak Sulaiman di Desa Karumbu Kecamatan Langgudu Kabupaten Bima sebagai berikut :

"Kalau ditanya, apa penggunaan ADD diawali dengan perencanaan. Ya, jawaban saya. Apa melibatkan masyarakat? Jawabannya ya. Ini pendapat saya ya. Ya, kami hanya dengardengar saja ada desa. Maklum hanya warga desa biasa. Tapi menurut saya, karena uang ini adalah uang Negara, ya pasti akan dikelola dengan baik. Ya, dipertanggungjawabkan dengan baik. Ini hanya pendapat pribadi saya ya. Tapi saya dengar juga dari Ketua RT saya, cukup ketat pencairan dananya" (Hasil Wawancara, Juni 2017)

Hasil wawancara lain dengan Bapak Drs. H. Taje Palna sebagai Ketua Lembaga Pemberdayaan Masyarakat Desa Karumbu Kecamatan Langgudu Kabupaten Bima sebagai berikut:
"Ini dana yang bersumber dari Negara ya. Berdasarkan ketentuannya. Pengelolaan keuangan Alokasi Dana Desa dimungkinkan untuk membiayai beberapa kegiatan lain. Secara detail jenis kegiatan yang boleh dibiayai oleh Alokasi Dana Desa diatur dengan jelas dalam petunjuk teknisnya. Tapi, perlu ditegaskan bahwa prioritas utama Alokasi Dana Desa adalah untuk pemberdayaan masyarakat. Nah, tergantung pada perencanaannya. Apakah melibatkan masyarakat, lembaga-lembaga desa dalam perencanaannya? Ini yang penting menurut saya. Dan di desa kami ini masyarakat dilibatkan" (Hasil Wawancara, Juni 2017)

Berdasarkan kutipan hasil wawancara tersebut menggambarkan bahwa perencanaan penggunaan keuangan Alokasi Dana Desa harus melibatkan masyarakat, lembagalembaga desa dan para pemangku kepentingan di Desa Karumbu Kecamatan Langgudu Kabupaten Bima, hasilnya dinilai sudah cukup baik dan telah sesuai dengan amanah Peraturan Pemerintah No. 8 Tahun 2017 tentang Perubahan Kedua PP 60 Tahun 2014 tentang Dana Desa yang bersumber dari Anggaran Pendapatan dan Belanja Negara.

Dengan demikian dapat disimpulkan bahwa perencanaan penggunaan keuangan Alokasi Dana Desa harus melibatkan masyarakat, lembaga-lembaga desa dan para pemangku kepentingan di Desa Karumbu Kecamatan Langgudu Kabupaten Bima, hasilnya dinilai sudah cukup baik dan telah sesuai dengan amanah Peraturan Pemerintah No. 8 Tahun 2017 tentang Perubahan Kedua PP 60 Tahun 2014 tentang Dana Desa yang bersumber dari Anggaran Pendapatan dan Belanja Negara.

2) Pelaksanaan penggunaan keuangan Alokasi Dana Desa harus melibatkan masyarakat, lembaga-lembaga desa dan para pemangku kepentingan

Indikator kedua dari fokus prinsip partisipatif dalam pengelolaan keuangan Alokasi Dana Desa, yaitu: pelaksanaan penggunaan keuangan Alokasi Dana Desa harus melibatkan masyarakat, lembagalembaga desa dan para pemangku kepentingan. 
Beberapa tahapan partisipasi masyarakat dalam penggunaan anggaran dana desa (Add) yaitu; tahap pertama masyarakat dapat berpartisipasi dalam perencanaan pembangunan melalui Musrenbang, dengan adanya musrenbangdes maka masayarakat terlibat langsung sebagai subjek atau pelaku dalam merencanakan pembangunan, yang diwakili oleh mansing-masing perwakilan dari pemangku kepentingan stakholder baik itu dari Kepala Dusun dan RT, tokoh masyarakat, ketua remaja di setiap pekadusan dan LSM, melalui perwakilan-perwakilan tersebut mereka membawa inspirasi berdasarkan kebutuhan masing-masing di setiap pedusunan, kelompak, lembaga dan lainnya, dalam pelaksanaan musrenbang yang dilaksanakan di awal tahun guna untuk perencanaan pembangunan pada tahun yang akan datang. Adapaun bentuk partisipasi masyarakat dalam perencanaan pembangunan pada saat Musrenbangdes yang diwakili oleh setiap perwakilan yaitu dapat berupa pikiran, inspirasi dan masukan guana pelaksanaan pembangunan desa pada tahun yang akan datang. Dalam hal Musrenbangdes sebagai ajang musyawarah untuk menetukan program pembangunan yang akan dilaksanakan untuk tahun berikutnya, masyarakat menyambut baik dan ikut berperan aktif dalam meberikan masukan dan inspirasi sesuai dengan kebutuhannya masing-masing.

Untuk tahap yang kedua yaitu pelaksanaan program, dalam pelaksaana program sebagai tindak lanjut dari Musyawarah Rencana Pembangunan Desa (Musrenbangdes), adapun bentuk partisipasi dalam pelaksanaan program, yaitu: partisipasi masyarakat yang berupa tenaga dalam bentuk membatuk kegiatan pembangunan fiscal; partisipasi masyarakat yang berupa pikiran dalam bentuk saran, keritikan dan masukan terhadap kegiatan program; partisipasi masyarakat dalam memberikan pasilitas atau peralata, dalam pelaksanaan program fiskal yang berupa cangkul, skop dan baskom; partisipasi masyarakat dalam bentuk memberikan kemampuan atau keahlian dibidang pertukangan.

Namun dari ke empat bentuk partisipasi masyarakat tersebut di atas, hanya sebagian kecil masyaraka yang turut serta dalam pelaksanaan program fisik, artinya partisipasi masyarakat dalam plaksanaan program masih kurang baik.

Tahap ketiga yaitu masyarakat dapat berpartisipasi dalam mengontrol atau mengawasi penggunaan anggaran dana desa melalui perencanaan dan pelaksanaan program, partisipasi masyarakat dalam mengontrol atau mengawasi penggunaan anggaran dana desa melalui perencanaan pembangunan atau pada saat pelaksanaan musrenbangdes dan pada saat pelaksanaan program mempunyai manfaat yang besar selain merencanakan maka pengangaran program sebelum pelaksanaan program masyarakat dapat mengetahui besaran dana yang dihabiskan oleh program yang dilaksanakan.

Untuk mengetahui bagaimana pelaksanaan penggunaan keuangan Alokasi Dana Desa harus melibatkan masyarakat, lembaga-lembaga desa dan para pemangku kepentingan di Desa Karumbu Kecamatan Langgudu Kabupaten Bima akan terlihat sebagaimana sajian wawancara berikut.

Hasil wawancara dengan salah seorang Kepala Dusun Oi Balu Desa Karumbu Kecamatan Langgudu Kabupaten Bima yang bernama Bapak Abdul Farid sebagai berikut:

"Ini pengalaman dan pengamatan saya ya. Partisipasi warga adalah proses ketika warga, sebagai individu maupun kelompok sosial dan organisasi, mengambil peran dalam proses perencanaan, pelaksanaan dan pemantauan kebijakan-kebijakan yang langsung mempengaruhi kehidupan mereka. Ya, termasuk penggunaan keuangan atau biaya Alokasi Dana Desa. Sebagai mitra kami selalu mengedepankan kebersamaan dan kesepahaman. Karenanya, di antara kami saling terbuka. Artinya, segala bentuk pengelolaan keuangan atau dana Alokasi Dana Desa harus terbuka. Semua orang boleh mengetahui tentang pengelolaan keuangan Alokasi Dana Desa. Keterbukaan ini terus kami pelihara selama ini. Dengan keterbukaan kecurigaan masyarakat, bias diredam. Banyak masalah di desa, karena kurangnya keterbukaan dalam penggunaan dana desa, 
termasuk Alokasi Dana Desa” (Hasil

Wawancara, Juni 2017)

Hasil wawancara dengan salah seorang warga yang bernama Bapak Ishaka di Desa Karumbu Kecamatan Langgudu Kabupaten Bima sebagai berikut:

"Ini pendapat saya ya. Alokasi dana desa (merupakan salah satu pendapatan desa yang berasal dari bantuan langsung pemerintah sebagai wujud pemerataan. Nah, karena dari pemerintah, ya harus dipertanggunjawabkan dengan baik. Pasti akan diperiksa oleh orang yang ahli dalam soal keuangan. Saya dengardengar sih, cukup baik pertanggungjawabannya. Ini pengakuan salah seorang teman yang dapat jatah pinjaman dana desa tersebut. Ini berdasarkan komentar teman saya itu" (Hasil Wawancara, Juni 2017)

Hasil wawancara lain dengan Bapak Hamdun sebagai Kepala Seksi Ekonomi / Pembangunan Desa Karumbu Kecamatan Langgudu Kabupaten Bima sebagai berikut:

"Kalau ditanya, apakah dalam pelaksanaan penggunaan keuangan ADD melibatkan masyarakat ya. Lembaga desa, bagaimana? Ya, wajib melibatkannya. Ada petunjuk teknis keuangan dalam pengelolaan keuangan Alokasi Dana Desa. Kami selalu mengacu atau berpedoman pada aturan tersebut. Untuk apa? Agar pengelolaan dana Alokasi Dana Desa dilaksanakan dengan tertib administrasi, transparan, akuntabel, efisien, dan efektif, tepat waktu serta terhindar dari penyimpangan. Nah, beberapa hal terakhir ini menjadi pertimbangan kami dalam pemanfaatan dana Alokasi Dana Desa" (Hasil Wawancara, Juni 2017)

Berdasarkan kutipan hasil wawancara tersebut menggambarkan bahwa persyaratan pengelolaan keuangan Alokasi Dana Desa harus terbuka di Desa Karumbu Kecamatan Langgudu Kabupaten Bima, hasilnya dinilai sudah cukup baik dan telah sesuai dengan amanah Peraturan Pemerintah No. 8 Tahun 2017 tentang Perubahan Kedua PP 60 Tahun 2014 tentang Dana Desa yang bersumber dari Anggaran Pendapatan dan Belanja Negara.

Dengan demikian dapat disimpulkan bahwa persyaratan pengelolaan keuangan Alokasi Dana Desa harus terbuka di Desa
Karumbu Kecamatan Langgudu Kabupaten Bima, hasilnya dinilai sudah cukup baik dan telah sesuai dengan amanah Peraturan Pemerintah No. 8 Tahun 2017 tentang Perubahan Kedua PP 60 Tahun 2014 tentang Dana Desa yang bersumber dari Anggaran Pendapatan dan Belanja Negara.

3) Penatausahaan penggunaan keuangan Alokasi Dana Desa harus melibatkan masyarakat, lembaga-lembaga desa, dan para pemangku kepentingan

Indikator ketiga dari fokus prinsip partisipatif dalam pengelolaan keuangan Alokasi Dana Desa, yaitu: penatausahaan penggunaan keuangan Alokasi Dana Desa harus melibatkan masyarakat, lembagalembaga desa, dan para pemangku kepentingan.

Kepala desa dalam melaksanakan penatausahaan keuangan desa harus menetapkan bendahara desa. Penetapan bendahara desa harus dilakukan sebelum dimulainya tahun anggaran bersangkutan dan berdasarkan keputusan kepala desa. Menurut Ardi Hamzah (2015) dikutip oleh Sujarweni (2015), Bendahara adalah perangkat desa yang ditunjuk oleh kepala desa dalam rangka pelaksanaan APBDesa. Bendahara desa wajib mempertanggungjawabkan uang melalui laporan pertanggungjawaban. Laporan pertanggungjawaban disampaikan setiap bulan kepada Kepala Desa dan paling lambat tanggal 10 bulan berikutnya.

Dalam Permendagri No. 113 tahun 2014 laporan pertanggungjawaban yang wajib dibuat oleh bendahara desa adalah sebagai berikut.

a. Buku kas umum. Buku kas umum digunakan untuk mencatat berbagai aktivitas yang menyangkut penerimaan dan pengeluaran kas, baik secara tunai maupun kredit, digunakan juga untuk mencatat mutasi perbankan atau kesalahan dalam pembukuan. Buku kas umum dapat dikatakan sebagai sumber dokumen transaksi.

b. Buku pembantu pajak. Buku pajak digunakan untuk membantu buku kas umum, dalam rangka penerimaan dan pengeluaran yang berhubungan dengan pajak. 
c. Buku bank. Buku bank digunakan untuk membantu buku kas umum, dalam rangka penerimaan dan pengeluaran yang berhubungan dengan uang bank

Pengelola pengelola keuangan Alokasi Dana Desa harus mampu mempertanggungjawabkan seluruh komponen pengelolaan pengelola keuangan Alokasi Dana Desa kepada masyarakat. Akuntabilitas tidak saja menyangkut proses pembelajaran, tetapi juga menyangkut pengelolaan keuangan, dan kualitas output.

Untuk mengetahui bagaimana penatausahaan penggunaan keuangan Alokasi Dana Desa harus melibatkan masyarakat, lembaga-lembaga desa, dan para pemangku kepentingan di Desa Karumbu Kecamatan Langgudu Kabupaten Bima akan terlihat sebagaimana sajian wawancara berikut.

Hasil wawancara dengan salah seorang warga yang bernama Bapak Yusran M. Sidik di Desa Karumbu Kecamatan Langgudu Kabupaten Bima sebagai berikut:

"Yang sering diundang untuk mengikuti acara-acara di desa, termasuk dalam hal penggunaan keuangan ADD. Ini pendapat saya selaku warga ya. Dalam pelaksanaan anggaran desa yang sudah ditetapkan sebelumnya timbul transaksi penerimaan dan pengeluaran desa. Semua penerimaan dan pengeluaran desa dalam rangka pelaksanaan kewenangan desa dilaksanakan melalui rekening kas desa. Jika desa yang belum memiliki pelayanan perbankan di wilayahnya maka pengaturannya ditetapkan oleh pemerintah kabupatena. Semua penerimaan dan pengeluaran desa harus didukung oleh bukti yang lengkap dan sah. Berdasarkan pengamatan saya berbulan-bulan bahkan hampir setahun terakhir ini. Pengelolaan keuangan Alokasi Dana Desa ada penanggungjawabnya. Ada satuan kerja atau pejabat penanggung jawab pengelolaan keuangan Alokasi Dana Desa. Saya pikir, penggunaan apa saja, apalagi soal uang yang harus dipertanggungjawabkan, pasti ada penanggungjawabnya. Di desa kami ini, pengelola keuangan Alokasi Dana Desa, sepengetahuan saya telah dibentuk penanggung jawab pengelolaan keuangan. Dana Alokasi Dana Desa yang saya maksudkan. Ketentuannya memang demikian" (Hasil Wawancara, Juni 2017)

Hasil wawancara dengan Bapak Sri Winarti sebagai Kepala Bidang Umum dan Aset Desa Karumbu Kecamatan Langgudu Kabupaten Bima sebagai berikut:

"Penatausahaan keuangan itu sangat penmting menurut saya. Jika tidak kita seperti menyerahkan diri ke dalam lembaga. Salah satu bentuk buku yang dipakai dalam penataan keuangan ADD yakni buku kas umum. Buku ini digunakan untuk mencatat berbagai aktivitas yang menyangkut penerimaan dan pengeluaran kas, baik secara tunai maupun kredit, digunakan juga untuk mencatat mutasi perbankan atau kesalahan dalam pembukuan. Buku kas umum dapat dikatakan sebagai sumber dokumen transaksi. Saya kebutukan, ditunjuk sebagai pembantu pengelola keuangan ADD. Maka dari itu berkewajiban untuk mengelola ADD sesuai peraturan yang berlaku. Sebab pengelolaan keuangan khususnya pengelolaan ADD ini merupakan sarana yang tepat sebagai perwujudan pemerintahan yang baik. Menerapkan prinsip akuntabilitas pada pengelolaan ADD tepat sebab dapat digunakan sebagai acuan kinerja penerintah desa dalam menjalankan tugasnya khususnya dalam pengelolaan keuangan. Ini komentar saya ya" (Hasil Wawancara, Juni 2017)

Hasil wawancara lain dengan $\mathrm{Ny}$. Siti Mariamah salah seorang tokoh masyarakat sekaligus Ketua PKK Desa Karumbu Kecamatan Langgudu Kabupaten Bima sebagai berikut:

"Seorang pengelola, menurut saya harus ahli administrasi keuangan. Karena keuangan Alokasi Dana Desa, langsung dikirim ke nomor rekening rutin pengelola keuangan Alokasi Dana Desa. Pengeluaran dana berdasarkan permintaan penanggungjawab kegiatan diajukan kepada kepala pengelola keuangan Alokasi Dana Desa dengan melampirkan proposal kegiatan. Pengambilan dana berikutnya oleh penanggungjawab kegiatan dapat direalisasikan setelah memberikan pertanggungjawaban dana yang diberikan sebelumnya kepada bendahara. Dan penerimaan dan pengeluaran dana dicatat dalam buku kas. Ini demi 
mempertanggungjawabkan penggunaan dana masyarakat" (Hasil Wawancara, Juni 2017)

Berdasarkan kutipan hasil wawancara tersebut menggambarkan bahwa penatausahaan penggunaan keuangan Alokasi Dana Desa harus melibatkan masyarakat, lembaga-lembaga desa, dan para pemangku kepentingan di Desa Karumbu Kecamatan Langgudu Kabupaten Bima, hasilnya dinilai sudah cukup baik dan telah sesuai dengan amanah Peraturan Pemerintah No. 8 Tahun 2017 tentang Perubahan Kedua PP 60 Tahun 2014 tentang Dana Desa yang bersumber dari Anggaran Pendapatan dan Belanja Negara.

Dengan demikian dapat disimpulkan bahwa penatausahaan penggunaan keuangan Alokasi Dana Desa harus melibatkan masyarakat, lembaga-lembaga desa, dan para pemangku kepentingan di Desa Karumbu Kecamatan Langgudu Kabupaten Bima, hasilnya dinilai sudah cukup baik dan telah sesuai dengan amanah Peraturan Pemerintah No. 8 Tahun 2017 tentang Perubahan Kedua PP 60 Tahun 2014 tentang Dana Desa yang bersumber dari Anggaran Pendapatan dan Belanja Negara.

4) Pelaporan dan pertanggugjawaban wajib penggunaan keuangan Alokasi Dana Desa harus melibatkan masyarakat, lembaga-lembaga desa, dan para pemangku kepentingan

Indikator keempat dari fokus prinsip partisipatif dalam pengelolaan keuangan Alokasi Dana Desa, yaitu: pelaporan dan pertanggugjawaban wajib penggunaan keuangan Alokasi Dana Desa harus melibatkan masyarakat, lembaga-lembaga desa, dan para pemangku kepentingan.

Akuntabilitas berarti kewajiban pembuat keputusan untuk: tanggap atas kebutuhan /hak pengguna jasa layanan pembangunan masyarakat, dan kemampuaan pengguna jasa untuk meminta pertanggung jawaban kepada pembuat kebijakan atau menejer atas janji atau keputusan mereka. Setiap anggota didorong untuk terbuka, kreatif, inovatif sehingga memungkinkan mencapai visi dalam sistem pengelola keuangan Alokasi Dana Desa. Akuntabilitas pengelola keuangan Alokasi Dana Desa berkaitan dengan adanya pengguna dana yang dikeluarkan dan hasil atau dampak yang diperoleh dari kegiatan yang dilaksanakan dengan dana tersebut.

Akuntabilitas menunjukan adanya tanggung gugat yaitu: adanya kesesuaiaan antara pelaksana dengan standar prosedur pelaksanaan, adanya sanksi yang disepakati atas kesalahan atau kelalaian atas pelaksanaan, dan adanya mekanisme pertanggung jawaban, laporan secara berkala, laporan pertanggung jawaban, sistem pengawasan, sistem reward dan punishemt.

Akuntabilitas adalah mempertanggungjawabkan pengelolaan sumber daya serta pelaksanaan kebijakan yang dipercayakan kepada entitas pelaporan dalam mencapai tujuan yang telah ditetapkan secara periodik.

Untuk mengetahui bagaimana waktu penyelesaian dan rincian biaya/tarif dan halhal lain yang yang berkaitan dengan proses pengelolaan keuangan Alokasi Dana Desa wajib diinformasikan di Desa Karumbu Kecamatan Langgudu Kabupaten Bima akan terlihat sebagaimana sajian wawancarat berikut.

Hasil wawancara dengan salah seorang warga yang bernama Bapak H. Muhammad Arif di Desa Karumbu Kecamatan Langgudu Kabupaten Bima sebagai berikut:

"Sesuai dengan ketentuan yang berlaku bahwa kepala desa adalah pemegang kekuasaan pengelolaan keuangan desa. Dalam melaksanakan kekuasaan pengelolaan keuangan desa, kepala desa menguasakan sebagian kekuasaannya kepada perangkat desa. Tentang pelaporan Alokasi Dana Desa, selama yang saya ketahui, pengelola melibatkan masyarakat, terutama lembagalembaga desa ini yang saya ketahui. Hal ini, juga terbukti bahwa dalam penggunaan ADD di desa ini berjalan dengan lancar dan tertib. Bagi saya, ini menunjukkan bahwa pengelolaan ADD, dilakukan secara terbuka dengan melibatkan semua unsur dalam masyarakat" (Hasil Wawancara, Juni 2017)

Hasil wawancara dengan Bapak Abdul Haris sebagai pengelola sekaligus Kepala Bidang Perencanaan dan Pelaporan Desa Karumbu Kecamatan Langgudu Kabupaten Bima sebagai berikut: 
"Bagi kami selaku pengelola, pelaporan merupakan salah satu bentuk pertanggungjawaban yang dilakukan pemerintah desa khususnya dalam pengelolaan ADD ini. Di Desa Karumbu sistem pelaporannya dilakukan melalui dua bentuk yakni secara subtantif dan normatif. Subtantifnya pemerintah desa melakukan pelaporan setiap 3-4 bulan sekali yakni melalui musyawarah yang dilakukan oleh pemerintah desa dengan mitra kerjanya" (Hasil Wawancara, Juni 2017)

Hasil wawancara lain dengan Bapak Muhammad Saleh salah seorang tokoh masyarakat sekaligus Kepala Dusun Oi Lanco Desa Karumbu Kecamatan Langgudu Kabupaten Bima sebagai berikut:

"Saya bukan membela pengelola keuangan Alokasi Dana Desa di desa kami ini ya. Dalam pengelolaan keuangan Alokasi Dana Desa, sudah terincikan alokasi pemanfaatannya. Pemanfaatan dana Alokasi Dana Desa pada pengelola keuangan Alokasi Dana Desa. Oleh karena itu, Alokasi Dana Desa tidak boleh digunakan asal-asalan atau untuk kegiatan yang tidak menguntungkan pengembangan desa. Dana Desa harus sesuai atau selaras dengan RPJMDes dan RKPDes. Prioritas penggunaan Alokasi Dana Desa untuk pembangunan desa harus memenuhi empat prioritas utama. Keempat prioritas utama penggunaan Alokasi Dana Desa yaitu; pemenuhan kebutuhan dasar, pembangunan sarana dan prasarana desa, pengembangan potensi ekonomi lokal, dan pemanfaatan sumber daya alam dan lingkungan secara berkelanjutan" (Hasil Wawancara, Juni 2017)

Berdasarkan kutipan hasil wawancara tersebut menggambarkan bahwa pelaporan yang berkaitan dengan proses pengelolaan keuangan Alokasi Dana Desa wajib diinformasikan kepada masyarakat di Desa Karumbu Kecamatan Langgudu Kabupaten Bima, hasilnya dinilai sudah cukup baik dan telah sesuai dengan amanah Peraturan Pemerintah No. 8 Tahun 2017 tentang Perubahan Kedua PP 60 Tahun 2014 tentang Dana Desa yang bersumber dari Anggaran Pendapatan dan Belanja Negara.

Dengan demikian dapat disimpulkan bahwa pelaporan penggunaan keuangan ADD sudah partisipatif dengan melibatkan unsur masyarakat, baik secara perorangan maupun secara kelembagaan. Formulir/daftar yang dipergunakan, dalam pembuatan pelaporan, terdiri atas: laporan semester pertama; laporan semester akhir tahun; dan laporan semester pertama berupa laporan realisasi APBDesa.

Pelaksana/Unit kerja yang terlibat: bendahara desa, sekretaris desa, kepala desa, Camat atau sebutan lain, dan Bupati. Keuangan desa adalah semua hak dan kewajiban desa yang dapat dinilai dengan uang serta segala sesuatu berupa uang dan barang yang berhubungan dengan pelaksanaan hak dan kewajiban Desa. Pengelolaan keuangan desa adalah keseluruhan kegiatan yang meliputi perencanaan, pelaksanaan, penatausahaan, pelaporan, dan pertanggungjawaban keuangan desa. Proses pelaporan dimulai dari membuat laporan semester pertama, laporan semester akhir tahun, laporan realisasi APBDesa dan diakhiri dengan penyampaian laporan-laporan tersebut kepada Bupati/Walikota melalui Camat.

Berdasarkan keempat indikator kaitan dengan fokus prinsip partisipatif dalam pengelolaan keuangan Alokasi Dana Desa, baik perencanaan penggunaan keuangan Alokasi Dana Desa harus melibatkan masyarakat, lembaga-lembaga desa dan para pemangku kepentingan, pelaksanaan penggunaan keuangan Alokasi Dana Desa harus melibatkan masyarakat, lembagalembaga desa dan para pemangku kepentingan, penatausahaan penggunaan keuangan Alokasi Dana Desa harus melibatkan masyarakat, lembaga-lembaga desa, dan para pemangku kepentingan, maupun pelaporan dan pertanggugjawaban wajib penggunaan keuangan Alokasi Dana Desa harus melibatkan masyarakat, lembagalembaga desa, dan para pemangku kepentingan, maka hasilnya telah sesuai dengan amanah Peraturan Menteri Dalam Negeri Republik Indonesia Nomor 113 Tahun 2014 Tentang Pengelolaan Keuangan Desa dan Undang-Undang RI Nomor 6 Tahun 2014 tentang Desa, maka hasilnya pelaksanaannya sudah berjalan sesuai dengan aturan pengelolaan keuangan Alokasi Dana Desa. 


\section{Penerapan prinsip transparasi penggunaan dana Alokasi Dana Desa}

Kaitan dengan fokus prinsip transparasi pengelolaan keuangan Alokasi Dana Desa, maka terdapat 4 (empat) indikatornya, yaitu: pertama, tersedianya informasi yang memadai pada setiap proses penyusunan dan pelaksanaan kebijakan pengelolaan keuangan Alokasi Dana Desa; kedua, adanya akses pada informasi cukup mudah dijangkau, bebas diperoleh dan tepat waktu dalam pengelolaan keuangan Alokasi Dana Desa; ketiga, adanya peraturan yang menjamin hak untuk mendapatkan informasi tentang pengelolaan keuangan Alokasi Dana Desa; dan keempat, tersedianya pusat informasi layanan pembangunan masyarakat bagi masyarakat seperti media, papan pengumuman, dan lain-lain dalam pengelolaan keuangan Alokasi Dana Desa.

Untuk mengetahui bagaimana transparansi pengelolaan keuangan Alokasi Dana Desa di Desa Karumbu Kecamatan Langgudu, maka akan terlihat sebagaimana sajian kutipan hasil wawancara secara berturut-turut berikut ini.

1) Tersedianya informasi yang memadai pada setiap proses penyusunan dan pelaksanaan kebijakan pengelolaan keuangan Alokasi Dana Desa

Indikator pertama dari fokus transparasi pengelolaan keuangan Alokasi Dana Desa, yaitu tersedianya informasi yang memadai pada setiap proses penyusunan dan pelaksanaan kebijakan pengelolaan keuangan Alokasi Dana Desa.

Transparansi adalah keterbukaan atas semua tindakan dan kebijakan yang diambil. Prinsip transparansi menciptakan kepercayaan timbal-balik antara pengelola keuangan Alokasi Dana Desa dan masyarakat melalui penyediaan informasi dan menjamin kemudahan di dalam memperoleh informasi yang akurat dan memadai.

Informasi adalah suatu kebutuhan penting bagi masyarakat untuk berpartisipasi dalam pengelolaan pengelola keuangan Alokasi Dana Desa. Berkaitan dengan hal tersebut pengelola keuangan Alokasi Dana Desa perlu proaktif memberikan informasi lengkap tentang kebijakan dan layanan yang disediakannya kepada masyarakat.

\section{Transparansi}

bermakna memberikan informasi keuangan yang terbuka dan jujur kepada masyarakat berdasarkan pertimbangan bahwa masyarakat memiliki hak untuk mengetahui secara terbuka dan menyeluruh atas pertanggungjawaban pemerintah dalam pengelolaan sumber daya yang dipercayakan kepadanya dan ketaatannya pada peraturan perundang-undangan.

Untuk mengetahui bagaimana tersedianya informasi yang memadai pada setiap proses penyusunan dan pelaksanaan kebijakan pengelolaan keuangan Alokasi Dana Desa di Desa Karumbu Kecamatan Langgudu Kabupaten Bima akan terlihat sebagaimana kutipan hasil wawancara berikut.

Untuk mengetahui mengenai tersedianya informasi yang memadai pada setiap proses penyusunan dan pelaksanaan kebijakan pengelolaan keuangan Alokasi Dana Desa di Desa Karumbu Kecamatan Langgudu Kabupaten Bima, akan disajikan sebagai berikut.

Hasil wawancara dengan salah seorang warga yang bernama Ibu Rahmi M. Ali di Desa Karumbu Kecamatan Langgudu Kabupaten Bima sebagai berikut:

"Sepengetahuan saya, pihak pengelola telah menyediakan informasi tentang pengelolaan keuangan Alokasi Dana Desa dengan sebaik-baiknya. Ya, termasuk dalam hal proses penyusunan dan pelaksanaan kebijakan pengelolaan keuangan Alokasi Dana Desa. Menurut saya, sudah sangat terbuka informasi tentang pengelolaan keuangan Alokasi Dana Desa. Atau dengan kata lain, masyarakat mudah mendapatkan informasi tentang pengggunaan dana Alokasi Dana Desa" (Hasil Wawancara, Juni 2017).

Hasil wawancara lain dengan salah seorang warga yang bernama Bapak Rusdin di Desa Karumbu Kecamatan Langgudu Kabupaten Bima sebagai berikut:

"Apapun alasannya pengelolaan keuangan Alokasi Dana Desa harus terang benderang. Alokasi dana desa yang dikucurkan pemerintah desa harus 
diumumkan secara transparan pada masyarakat, khususnya warga desa setempat. Hal tersebut untuk menghindari terjadinya penyelewengan dana, kecurigaan publik, dan supaya pembangunan di desa dapat berlangsung secara kondusif. Ini pendapat saya ya" (Hasil Wawancara, Juni 2017).

Hasil wawancara lain dengan Bapak Syahrul, S.Pd salah tokoh masyarakat sekaligus Kepala Dusun Kananga Desa Karumbu Kecamatan Langgudu Kabupaten Bima sebagai berikut:

"Kami dari pihak pengelola selalu terbuka dan bersikap transparansi jika ada halhal yang perlu diketahui bersama oleh masyarakat. Baik yang berkenaan dengan penyelenggaraan pembangunan, maupun untuk menggalang dana masyarakat dalam rangka pembiayaan penyelenggaraan pembangunan ataupun hal-hal lain yang berkaitan langsung dengan pembangunan masyarakat. Termasuk dalam pengelolaan keuangan Alokasi Dana Desa. Hal ini kami dilakukan agar masyarakat ikut berpartisipasi dan mendukung peningkatan mutu dan pemerataan pembangunan masyarakat. Kalau kami tutup-tutupi, justru masyarakat tidak mau membantu kalau kami meminta bantuan dalam membangun desa" (Hasil Wawancara, Juni 2017).

Berdasarkan kutipan hasil wawancara tersebut menggambarkan bahwa tersedianya informasi yang memadai pada setiap proses penyusunan dan pelaksanaan kebijakan pengelolaan keuangan Alokasi Dana Desa di Desa Karumbu Kecamatan Langgudu Kabupaten Bima, hasilnya dinilai sudah cukup baik dan telah sesuai dengan amanah Peraturan Pemerintah No. 8 Tahun 2017 tentang Perubahan Kedua PP 60 Tahun 2014 tentang Dana Desa yang bersumber dari Anggaran Pendapatan dan Belanja Negara.

Dengan demikian dapat disimpulkan bahwa tersedianya informasi yang memadai pada setiap proses penyusunan dan pelaksanaan kebijakan pengelolaan keuangan Alokasi Dana Desa di Desa Karumbu Kecamatan Langgudu Kabupaten Bima, hasilnya dinilai sudah cukup baik dan telah sesuai dengan amanah Peraturan Pemerintah No. 8 Tahun 2017 tentang Perubahan Kedua
PP 60 Tahun 2014 tentang Dana Desa yang bersumber dari Anggaran Pendapatan dan Belanja Negara.

2) Adanya akses pada informasi cukup mudah dijangkau, bebas diperoleh dan tepat waktu dalam pengelolaan keuangan Alokasi Dana Desa

Indikator kedua dari fokus transparasi pengelolaan keuangan Alokasi Dana Desa, yaitu adanya akses pada informasi cukup mudah dijangkau, bebas diperoleh dan tepat waktu dalam pengelolaan keuangan Alokasi Dana Desa. Pengelola keuangan Alokasi Dana Desa perlu mendayagunakan berbagai jalur komunikasi seperti melalui brosur, leaflet, pengumuman melalui koran, maupun radio. Pengelola keuangan Alokasi Dana Desa perlu menyiapkan kebijakan yang jelas tentang cara mendapatkan informasi. Kebijakan ini akan memperjelas bentuk informasi yang dapat diakses masyarakat ataupun bentuk informasi yang bersifat rahasia, bagaimana cara mendapatkan informasi, lama waktu mendapatkan informasi serta prosedur pengaduan apabila informasi tidak sampai kepada masyarakat.

Transparansi dan akuntabilitas merupakan konsep yang berkaitan erat satu dengan yang lain, karena tanpa transparansi tidak mungkin ada akuntabilitas. Sebaliknya transparansi tidak akan banyak bermanfaat tanpa dilengkapi dengan akuntabilitas. Seperti halnya di bidang kebijakan publik yang lain, keberadaan transparansi dan akuntabilitas merupakan syarat mutlak untuk membangun kebijakan dan institusi yang efektif, efisien, dan adil. Lingkup transparansi dan akuntabilitas harus menjangkau beberapa tingkat kebijakan mulai dari perumusan kebijakan, pengambilan keputusan, sampai pada pelaksanaannya yang terjadi di segenap institusi.

Untuk mengetahui bagaimana adanya akses pada informasi cukup mudah dijangkau, bebas diperoleh dan tepat waktu dalam pengelolaan keuangan Alokasi Dana Desa di Desa Karumbu Kecamatan Langgudu Kabupaten Bima, akan terlihat sebagaimana kutipan hasil wawancara berikut.

Hasil wawancara dengan salah seorang warga yang bernama Bapak 
Muhammad Abbas di Desa Karumbu Kecamatan Langgudu Kabupaten Bima sebagai berikut:

"Saya merasa, pengelola keuangan Alokasi Dana Desa telah menyediakan informasi tentang pengelolaan keuangan Alokasi Dana Desa dan mudah dijangkau. Karena sudah ada papan pengumuman. Kami selaku warga bebas mendapatkan informasi tentang pengelolaan keuangan Alokasi Dana Desa. Yang saya tahu, masyarakat umum juga bisa mendapatkan informasi tentang pengelolaan keuangan Alokasi Dana Desa, baik untuk pemerintah desa, pengelola keuangan Alokasi Dana Desa, maupun untuk masyarakat umum" (Hasil Wawancara, Juni 2017).

Hasil wawancara dengan salah seorang warga yang bernama Bapak Karim di Desa Karumbu Kecamatan Langgudu Kabupaten Bima sebagai berikut:

"Saya setuju dengan jawaban salah seorang warga tadi. Dan memang begitu kenyataannya. Lepas dari itu, dana desa pada intinya dipergunakan untuk kesejahteraan warga, mendorong pembangunan infrastruktur, perekonomian warga dan jenis pemberdayaan lainnya. Transparansi mutlak dilakukan pemerintah desa agar kepercayaan publik dan warga akan penggunaan dana desa menguat. Ini penting menurut saya" (Hasil Wawancara, Juni 2017).

Hasil wawancara lain dengan Bapak Wahyudin, S.Sos sebagai Sekretaris Desa Karumbu Kecamatan Langgudu Kabupaten Bima sebagai berikut:

"Kami dari pihak pengelola keuangan Alokasi Dana Desa telah menyiapkan dengan sebaik-baiknya tentang pengelolaan keuangan Alokasi Dana Desa. Jadi informasi-informasi yang berkenaan dengan pengelolaan keuangan Alokasi Dana Desa kami sudah menyiapkannya dengan sebaik-baiknya. Pemerintah desa maupun masyarakat yang mau infomasi tentang pengelolaan keuangan Alokasi Dana Desa, ya silahkan. Bahkan kami telah membuatnya dalam bentuk laporan resmi" (Hasil Wawancara, Juni 2017).

Berdasarkan kutipan hasil wawancara tersebut menggambarkan bahwa adanya akses pada informasi cukup mudah dijangkau, bebas diperoleh dan tepat waktu dalam pengelolaan keuangan Alokasi Dana Desa di Desa Karumbu Kecamatan Langgudu Kabupaten Bima, hasilnya dinilai sudah cukup baik dan telah sesuai dengan amanah Peraturan Pemerintah No. 8 Tahun 2017 tentang Perubahan Kedua PP 60 Tahun 2014 tentang Dana Desa yang bersumber dari Anggaran Pendapatan dan Belanja Negara.

Dengan demikian dapat disimpulkan bahwa adanya akses pada informasi cukup mudah dijangkau, bebas diperoleh dan tepat waktu dalam pengelolaan keuangan Alokasi Dana Desa di Desa Karumbu Kecamatan Langgudu Kabupaten Bima, hasilnya dinilai sudah cukup baik dan telah sesuai dengan amanah Peraturan Pemerintah No. 8 Tahun 2017 tentang Perubahan Kedua PP 60 Tahun 2014 tentang Dana Desa yang bersumber dari Anggaran Pendapatan dan Belanja Negara.

3) Adanya peraturan yang menjamin hak untuk mendapatkan informasi tentang pengelolaan keuangan Alokasi Dana Desa

Indikator ketiga dari fokus transparasi pengelolaan keuangan Alokasi Dana Desa, yaitu adanya peraturan yang menjamin hak untuk mendapatkan informasi tentang pengelolaan keuangan Alokasi Dana Desa.

Transparan di bidang manajemen berarti adanya keterbukaan dalam mengelola suatu kegiatan. Di lembaga pembangunan masyarakat, bidang manajemen keuangan yang transparan berarti adanya keterbukaan dalam manajemen keuangan lembaga pembangunan masyarakat, yaitu keterbukaan sumber keuangan dan jumlahnya, rincian penggunaan, dan pertanggungjawabannya harus jelas sehingga bisa memudahkan pihakpihak yang berkepentingan untuk mengetahuinya.

Transparansi keuangan sangat diperlukan dalam rangka meningkatkan dukungan masyarakat dan pemerintah dalam penyelenggaraan seluruh program pembangunan masyarakat. Di samping itu transparansi dapat menciptakan kepercayaan timbal balik antara pemerintah, masyarakat, dan pengelola keuangan Alokasi Dana Desa melalui penyediaan informasi dan menjamin 
kemudahan di dalam memperoleh informasi yang akurat dan memadai.

Beberapa informasi keuangan yang bebas diketahui oleh semua warga misalnya rencana anggaran pendapatan dan belanja pengelola keuangan Alokasi Dana Desa bisa ditempel di papan pengumuman di ruang umum atau di depan ruang kantor desa sehingga bagi siapa saja yang membutuhkan informasi itu dapat dengan mudah mendapatkannya. Masyarakat bisa mengetahui berapa jumlah uang yang diterima pengelola keuangan Alokasi Dana Desa dari pemerintah dan digunakan untuk apa saja uang itu. Perolehan informasi ini menambah kepercayaan masyarakat terhadap pengelola keuangan Alokasi Dana Desa.

Untuk mengetahui bagaimana adanya peraturan yang menjamin hak untuk mendapatkan informasi tentang pengelolaan keuangan Alokasi Dana Desa di Desa Karumbu Kecamatan Langgudu Kabupaten Bima akan terlihat sebagaimana kutipan hasil wawancara berikut.

Hasil yang diperoleh di atas, didukung pula oleh wawancara dengan Bapak Abdullah Ahmad selaku warga sebagaimana berikut ini:

"Benar. Saya dan masyarakat lainnya sangat merasakan. Bahwa memang ada peraturan-peraturan pengelola keuangan Alokasi Dana Desa yang berkaitan dengan pengelolaan keuangan Alokasi Dana Desa. Kami mendapatkan informasi tentang aturanaturan itu dengan jelas. Kami dijelaskan oleh pihak pengelola keuangan Alokasi Dana Desa tentang pengelolaan keuangan Alokasi Dana Desa. Nah, hal ini sangat kami rasakan pada pengelola di desa ini" (Hasil Wawancara, Juni 2017).

Hasil yang diperoleh di atas, didukung pula oleh wawancara dengan Ibu Aminah selaku warga Desa Karumbu sebagaimana berikut ini:

"Saya setuju. Memang harus ada peraturan-peraturan pengelola keuangan Alokasi Dana Desa. Jika tidak. Akan kacau jadinya. Dan yang saya lihat, pengelola di desa kami ini, cukup baik. Lepas dari soal peraturan tersebut, yang saya sangat setuju, program pembangunan di desa kami ini menggunakan gaya padat karya. Jadi untuk membangun infrastruktur dan pembangunan desa harus dilakukan melalui padat karya dan tidak diperbolehkan melibatkan orang ketiga atau diproyekkan. Artinya tenaga pekerjanya melibatkan warga wilayah desa tersebut, bahkan bila perlu bahan bakunya juga dibeli dari warga setempat" (Hasil Wawancara, Juni 2017).

Hasil wawancara lain dengan Bapak Abdul Malik Ahmad sebagai Ketua BPD Desa Karumbu Kecamatan Langgudu Kabupaten Bima sebagai berikut:

"Kami bersama pemerintah desa telah membuat peraturan-peraturan tentang pengelolaan keuangan Alokasi Dana Desa berkenaan dengan pengelolaan keuangan Alokasi Dana Desa. Peraturan yang kami maksud, tidak jauh dari aturan pengelolaan keuangan Alokasi Dana Desa yang telah dikeluarkan oleh pemerintah. Sebagaimana kita maklumi, dana Alokasi Dana Desa kan berlaku nasional. Nah, penggunaannya tidak boleh melanggar pedoman pemanfaatan dana Alokasi Dana Desa" (Hasil Wawancara, Juni 2017).

Berdasarkan kutipan hasil wawancara tersebut menggambarkan bahwa adanya peraturan yang menjamin hak untuk mendapatkan informasi tentang pengelolaan keuangan Alokasi Dana Desa di Desa Karumbu Kecamatan Langgudu Kabupaten Bima, hasilnya dinilai sudah cukup baik dan telah sesuai dengan amanah Peraturan Pemerintah No. 8 Tahun 2017 tentang Perubahan Kedua PP 60 Tahun 2014 tentang Dana Desa yang bersumber dari Anggaran Pendapatan dan Belanja Negara.

Dengan demikian dapat disimpulkan bahwa adanya peraturan yang menjamin hak untuk mendapatkan informasi tentang pengelolaan keuangan Alokasi Dana Desa di Desa Karumbu Kecamatan Langgudu Kabupaten Bima, hasilnya dinilai sudah cukup baik dan telah sesuai dengan amanah Peraturan Pemerintah No. 8 Tahun 2017 tentang Perubahan Kedua PP 60 Tahun 2014 tentang Dana Desa yang bersumber dari Anggaran Pendapatan dan Belanja Negara.

4) Tersedianya pusat informasi layanan pembangunan masyarakat bagi masyarakat seperti media, papan 


\section{pengumuman, dan lain-lain dalam pengelolaan keuangan Alokasi Dana Desa}

Indikator keempat dari fokus transparasi pengelolaan keuangan Alokasi Dana Desa, yaitu tersedianya pusat informasi layanan pembangunan masyarakat bagi masyarakat seperti media, papan pengumuman, dan lain-lain dalam pengelolaan keuangan Alokasi Dana Desa. Dalam kontek pembangunan masyarakat, istilah transparansi sangatlah jelas yaitu kepolosan apa adanya, tidak bohong, jujur dan terbuka terhadap publik tentang apa yang dikerjakan oleh pengelola keuangan Alokasi Dana Desa, dimana data yang dilaporkan pengelola keuangan Alokasi Dana Desa mencerminkan realitas yang sebenarnya dan setiap perubahan harus diungkapkan secara sebenarnya dan dengan segera kepada semua pihak yang terkait (stakeholders).

Transparansi ditujukan untuk membangun kepercayaan dan keyakinan kepada pengelola keuangan Alokasi Dana Desa bahwa pengelola keuangan Alokasi Dana Desa adalah organisasi pelayanan pembangunan masyarakat yang bersih dan berwibawa, bersih dalam arti tidak KKN dan berwibawa dalam arti profesional.

Transparansi bertujuan untuk menciptakan kepercayaan timbal balik antara pengelola keuangan Alokasi Dana Desa dan masyarakat melalui informasi yang memadai dan menjamin kemudahan dalam memperoleh informasi yang akurat.

Untuk mengetahui mengenai tersedianya pusat informasi layanan pembangunan masyarakat bagi masyarakat seperti media, papan pengumuman, dan lainlain dalam pengelolaan keuangan Alokasi Dana Desa di Desa Karumbu Kecamatan Langgudu Kabupaten Bima, maka akan tampak dengan jelas tanggapan informan sebagaimana sajian wawancara berikut ini.

Hasil wawancara dengan salah seorang warga yang bernama Bapak Burhan di Desa Karumbu Kecamatan Langgudu Kabupaten Bima sebagai berikut:

"Berdasarkan pengamatan saya, ada papan informasi. Banyak informasi-informasi yang dipasang di papan itu. Nah, termasuk pengelolaan keuangan Alokasi Dana Desa. Selain papan informasi, saya pernah melihat di ruangan ketua pengelola keuangan Alokasi Dana Desa, ada juga informasi tentang pengelolaan keuangan Alokasi Dana Desa. Tapi, untuk bagian administrasi, tidak ada papannya, tapi dalam bentuk laporan" (Hasil Wawancara, Juni 2017).

Hasil wawancara dengan salah seorang warga yang bernama Bapak Ishaka di Desa Karumbu Kecamatan Langgudu Kabupaten Bima sebagai berikut:

"Saya juga tahu ada papan informasi. Gunanya menurut saya, agar warga ketahui bahwa sedang dilakukan program pemberdayaan masyarakat desa. Saya setuju dengan info yang ada di papan infor tersebut. Katanya, mengutamakan padat karya dalam pelaksanaan proyeknya. Untuk apa? Ya, agar roda perekonomian masyarakat di wilayah desa tersebut bisa berkembang. Karena tujuan dari adanya dana desa ini untuk mensejahterakan rakyat dan memajukan seluruh desa" (Hasil Wawancara, Juni 2017).

Hasil wawancara lain dengan Bapak Mukhlis salah seorang pengelola sekaligus sebagai Kepala Urusan Keuangan Desa Karumbu Kecamatan Langgudu Kabupaten Bima sebagai berikut:

"Kami selaku pihak pengelola keuangan Alokasi Dana Desa telah menyiapkan media atau alat untuk informasi. Kami siapkan papan informasi. Banyak hal yang kami informasikan melalui papan informasi tersebut. Termasuk pengelolaan keuangan Alokasi Dana Desa. Memang ada ketentuan seperti itu. Harus terbuka kepada semua pihak. Laporan penggunaannya juga kami sudah buatkan. Sehingga bagi siapapun yang membutuhkan informasi tentang pengelolaan keuangan Alokasi Dana Desa, tidak menemui kesulitan. Intinya, kami harus terbuka" (Hasil Wawancara, Juni 2017).

Berdasarkan kutipan hasil wawancara tersebut menggambarkan bahwa tersedianya pusat informasi layanan pembangunan masyarakat bagi masyarakat seperti media, papan pengumuman, dan lain-lain dalam pengelolaan keuangan Alokasi Dana Desa di Desa Karumbu Kecamatan Langgudu Kabupaten Bima, hasilnya dinilai sudah 
cukup baik dan telah sesuai dengan amanah Peraturan Pemerintah No. 8 Tahun 2017 tentang Perubahan Kedua PP 60 Tahun 2014 tentang Dana Desa yang bersumber dari Anggaran Pendapatan dan Belanja Negara.

Dengan demikian dapat disimpulkan bahwa tersedianya pusat informasi layanan pembangunan masyarakat bagi masyarakat seperti media, papan pengumuman, dan lainlain dalam pengelolaan keuangan Alokasi Dana Desa di Desa Karumbu Kecamatan Langgudu Kabupaten Bima, hasilnya dinilai sudah cukup baik dan telah sesuai dengan amanah Peraturan Pemerintah No. 8 Tahun 2017 tentang Perubahan Kedua PP 60 Tahun 2014 tentang Dana Desa yang bersumber dari Anggaran Pendapatan dan Belanja Negara.

Berdasarkan keempat indikator kaitan dengan fokus transparasi pengelolaan keuangan Alokasi Dana Desa, baik tersedianya informasi yang memadai pada setiap proses penyusunan dan pelaksanaan kebijakan pengelolaan keuangan Alokasi Dana Desa, adanya akses pada informasi cukup mudah dijangkau, bebas diperoleh dan tepat waktu dalam pengelolaan keuangan Alokasi Dana Desa, adanya peraturan yang menjamin hak untuk mendapatkan informasi tentang pengelolaan keuangan Alokasi Dana Desa, tersedianya pusat informasi layanan pembangunan masyarakat bagi masyarakat seperti media, papan pengumuman, maupun lain-lain dalam pengelolaan keuangan Alokasi Dana Desa, maka hasilnya pelaksanaannya sudah berjalan sesuai dengan aturan pengelolaan keuangan Alokasi Dana Desa.

\section{Penyajian Data}

Langkah analisis selanjutnya setelah data direduksi adalah penyajian (display) data. Penyajian data merupakan analisis merancang deretan dan kolom sebuah matriks untuk data kualitatif dan menentukan jenis serta bentuk data yang dimasukkan ke dalam kotak-kotak matriks (Miles, 1992:17-18). Penyajian data diarahkan agar data hasil reduksi terorganisasikan, tersusun dalam dapat dilakukan dalam bentuk uraian naratif, bagan, hubungan antar kategori, diagram alur flow chart), dan lain sejenisnya. Penyajian data dalam bentuk-bentuk tersebmerencanakPada tahap ini, data yang telah diberi kode sesuai dengan permasalahan kemudian disajikan dalam bentuk matrik. Jadi peneliti dapat menguasai data dan tidak dipersulit dengan data yang bertumpuktumpuk. Pada tahap ini, data yang telah diberi kode sesuai dengan permasalahan kemudian disajikan dalam bentuk matrik. Jadi peneliti dapat menguasai data dan tidak dipersulit dengan data yang bertumpuk-tumpuk.

\section{Verifikasi dan Penarikan Kesimpulan}

Verifikasi atau penarikan kesimpulan adalah langkah terakhir dari analisis data. Penarikan kesimpulan harus berdasarkan pada reduksi data dan sajian data. Dengan demikian komponen saling mempengaruhi, jika terdapat kekurangan data dalam pemeriksaan kesimpulan, maka peneliti dapat mengamati catatan lapangan. Jika masih tidak ditemukan, maka kembali melakukan pengumpulan data.

Tahap penarikan kesimpulan berdasarkan temuan dan melakukan verifikasi data. Kesimpulan awal yang dikemukakan masih bersifat sementara dan akan berubah bila ditemukan bukti-bukti buat yang mendukung tahap pengumpulan data berikutnya. Proses untuk mendapatkan buktibukti inilah yang disebut sebagai verifikasi data. Apabila kesimpulan yang dikemukakan pada tahap awal didukung oleh bukti-bukti yang kuat dalam arti konsisten dengan kondisi yang ditemukan saat peneliti kembali ke lapangan maka kesimpulan yang diperoleh merupakan kesimpulan yang kredibel.

Langkah verifikasi yang dilakukan peneliti sebaiknya masih tetap terbuka untuk menerima masukan data, walaupun data tersebut adalah data yang tergolong tidak bermakna. Namun demikian peneliti pada tahap ini sebaiknya telah memutuskan akan data yang mempunyai makna dengan data yang tidak diperlukan atau tidak bermakna. Data yang dapat diproses dalam analisis lebih lanjut seperti absah, berbobot, dan kuat sedang data lain yang tidak menunjang, lemah, dan menyimpang jauh dari kebiasaan harus dipisahkan.

Kesimpulan yang dapat peneliti simpulkan, setelah dilakukan reduksi dan display data sebagai berikut: 
1. Berdasarkan keempat sub fokus kaitan dengan prinsip partisipatif dalam pengelolaan keuangan Alokasi Dana Desa, baik perencanaan penggunaan keuangan Alokasi Dana Desa harus melibatkan masyarakat, lembaga-lembaga desa dan para pemangku kepentingan, pelaksanaan penggunaan keuangan Alokasi Dana Desa harus melibatkan masyarakat, lembaga-lembaga desa dan para pemangku kepentingan, penatausahaan penggunaan keuangan Alokasi Dana Desa harus melibatkan masyarakat, lembaga-lembaga desa, dan para pemangku kepentingan, maupun pelaporan dan pertanggugjawaban wajib penggunaan keuangan Alokasi Dana Desa harus melibatkan masyarakat, lembagalembaga desa, dan para pemangku kepentingan, maka hasilnya telah sesuai dengan amanah Peraturan Menteri Dalam Negeri Republik Indonesia Nomor 113 Tahun 2014 Tentang Pengelolaan Keuangan Desa dan Undang-Undang RI Nomor 6 Tahun 2014 tentang Desa.

2. Berdasarkan keempat indikator kaitan dengan fokus prinsip transparansi dalam penggunaan Alokasi Dana Desa, tersedianya informasi yang memadai pada setiap proses penyusunan dan pelaksanaan kebijakan pengelolaan keuangan Alokasi Dana Desa, adanya akses pada informasi cukup mudah dijangkau, bebas diperoleh dan tepat waktu dalam pengelolaan keuangan Alokasi Dana Desa, adanya peraturan yang menjamin hak untuk mendapatkan informasi tentang pengelolaan keuangan Alokasi Dana Desa, tersedianya pusat informasi layanan pembangunan masyarakat bagi masyarakat seperti media, papan pengumuman, maupun lain-lain dalam pengelolaan keuangan Alokasi Dana Desa, maka hasilnya telah sesuai dengan amanah Peraturan Menteri Dalam Negeri Republik Indonesia Nomor 113 Tahun 2014 Tentang Pengelolaan Keuangan Desa dan Undang-Undang RI Nomor 6 Tahun 2014 tentang Desa.

\section{Pembahasan Hasil Penelitian}

1. Prinsip partisipatif dalam penggunaan keuangan Alokasi Dana Desa

Berdasarkan data penelitian yang diperoleh, baik melalui wawancara, pengamatan dan dokumentasi, maka dapat disimpulkan bahwa penggunaan keuangan Alokasi Dana Desa di Desa Karumbu Kecamatan Langgudu Kabupaten Bima, dapat disimpulkan telah dilaksanakan dengan prinsip pengelolaan keuangan yakni partisipatif.

Prinsip partisipatif mempunyai pengertian bahwa setiap tindakan dilakukan dengan mengikutsertakan keterlibatan masyarakat baik secara langsung maupun tidak langsung melalui lembaga perwakilan yang dapat menyalurkan aspirasinya.

Partisipasi menurut (LAN dan BPKP, 2000) adalah setiap warganegara mempunyai suara dalam pembuatan keputusan, baik secara langsung maupun melalui intermediasi institusi legitimasi yang mewakili kepentingannya. Partisipasi ini dibangun atas dasar kebebasan berasosiasi dan berbicara serta berpartisipasi secara konstruktif. Dalam Permendagri No. 37 Tahun2007 tentang Pengelolaan Keuangan Desa, partisipasi memakai kata-kata partisipatif, yaitu keikutsertaan dan keterlibatan masyarakat secara aktif dalam proses pembangunan (Permendagri No.37 Tahun 2007).

Partisipasi masyarakat dalam penentuan kebijakan publik menjadi kekuatan pendorong untuk mempercepat terpenuhinya prinsip akuntabilitas dari penyelenggara pemerintahan di desa. Dalam penganggaran partisipasi masyarakat sangat penting untuk mencegah kebijakan-kebijakan yang menyimpang. Prinsip dan indikator partisipasi masyarakat dalam pengganggaran menurut (Gatot Sulistioni, Hendriadi, 2004) mencakup hal-hal berikut : a) Adanya akses bagi partisipasi aktif publik dalam proses perumusan program dan pengambilan keputusan anggaran; b) Adanya peraturan yang memberikan tempat ruang kontrol oleh lembaga independen dan masyarakat baik secara perorangan maupun kelembagaan sebagai media check and balances. 3) Adanya sikap proaktif pemerintah daerah untuk 
mendorong partisipasi warga pada proses penganggaran. Hal ini mengingat kesenjangan yang tajam antara kesadaran masyarakat tentang cara berpartisipasi yang efektif dan cita-cita mewujudkan APBD yang aspiratif.

Pengelolaan keuangan desa, sejak tahap perencanaan, pelaksanaan, penatausahaan, pelaporan dan pertanggugjawaban wajib melibatkan masyarakat para pemangku kepentingan di desa serta masyarakat luas, utamanya kelompok marjinal sebagai penerima manfaat dari program/kegiatan pembangunan di desa.

Apa yang ditemukan dalam penelitin ini sesuai dengan penjelasan tentang asas-asas penyelenggaraan negara adalah mengacu pada Pasal 3 angka 7 Undang - Undang Nomor 28 Tahun 1999 tentang Penyelenggaraan Negera yang Bersih dan Bebas Korupsi Kolusi dan Nepotisme (KKN), partisipasi adalah keikutsertaan masyarakat untuk mengakomodasikan kepentingan mereka dalam proses penyusunan rencana pembangunan.

Selain prinsip partisipatif tersebut, asas-asas umum pengelolaan keuangan dilakukan secara tertib, taat pada peraturan perundang-undangan, efisien, ekonomis, efektif dengan memperhatikan asas keadilan, kepatutan dan manfaat untuk masyarakat. Hal ini dituangkan dalam pasal 4 Peraturan Pemerintah No. 58 Tahun 2005. Peraturan ini adalah penjabaran dari paket undang-undang keuangan, yakni, Undang-Undang No. 17 Tahun 2003 tentang Keuangan Negara, Undang-Undang No. 1 tahun 2004 tentang Perbendaharaan Negara, dan UndangUndang No. 15 Tahun 2004 tentang Pemeriksaan Pengelolaan dan Tanggungjawab Keuangan Negara.

Tertib dan disiplin anggaran yaitu pengelolaan keuangan desa harus mengacu pada aturan atau pedoman yang melandasinya. Beberapa disiplin anggaran yang perlu diperhatikan dalam Pengelolaan Keuangan

Desa yaitu: pendapatan yang direncanakan merupakan perkiraan yang terukur secara rasional yang dapat dicapai untuk setiap sumber pendapatan, sedangkan belanja yang dianggarkan merupakan batas tertinggi pengeluaran belanja; pengeluaran harus didukung dengan adanya kepastian tersedianya penerimaan dalam jumlah yang cukup dan tidak dibenarkan melaksanakan kegiatan yang belum tersedia atau tidak mencukupi kredit anggarannya dalam APB Desa/Perubahan APB Desa; semua penerimaan dan pengeluaran daerah dalam tahun anggaran yang bersangkutan harus dimasukan dalam APB Desa dan dilakukan melalui Rekening Kas Desa.

Keuangan Desa menurut UU Desa adalah semua hak dan kewajiban desa yang dapat dinilai dengan uang serta segala sesuatu berupa uang dan barang yang berhubungan dengan pelaksanaan hak dan kewajiban Desa. Hak dan kewajiban tersebut menimbulkan pendapatan, belanja, pembiayaan yang perlu diatur dalam pengelolaan keuangan desa yang baik. Siklus pengelolaan keuangan desa meliputi perencanaan, pelaksanaan, penatausahaan, pelaporan, dan pertanggungjawaban, dengan periodisasi 1 (satu) tahun anggaran, terhitung mulai tanggal 1 Januari sampai dengan 31 Desember.

Beberapa prinsip pengelolaan keuangan desa yang baik: rancangan APBDES yang berbasis program; rancangan APBDES yang berdasarkan pada partisipasi unsur-unsur masyarakat dari bawah; keuangan yang dikelola secara bertanggungjawab (akuntabilitas), keterbukaan (transparansi) dan daya tanggap (responsivitas) terhadap priotitas kebutuhan masyarakat; dan memelihara dan mengembangkan pemerintahan, pembangunan dan kemasyarakatan (pelayanan dan pemberdayaan).

Perencanaan program yang partisipatif dari bawah dan menyeluruh di atas memang membutuhkan tenaga besar, waktu panjang dan melelahkan. Banyak orang yang jengkel dan tidak sabar dengan partisipasi karena terlalu banyak bicara, lambat, dan katanya tidak membuahkan hasil. Tetapi, partisipasi sebenarnya akan memberikan manfaat yang sangat besar pada pemerintah dan masyarakat desa, di antaranya:

1. Partisipasi adalah perwujudan kedaulatan rakyat, yang menempatkan 
mereka sebagai awal dan tujuan pembangunan.

2. Partisipasi menimbulkan rasa harga diri dan kemampuan pribadi untuk turut serta dalam menentukan keputusan yang menyangkut masyarakat. Dengan kalimat lain, partisipasi adalah bentuk "memanusiakan manusia".

3. Partisipasi adalah proses saling belajar bersama antara pemerintah dan masyarakat, sehingga bisa saling menghargai, mempercayai, dan menumbuhkan sikap yang arif.

4. Partisipasi menciptakan suatu lingkaran umpan balik informasi tentang aspirasi, kebutuhan dan kondisi masyarakat.

5. Partisipasi merupakan kunci pemberdayaan dan kemandirian masyarakat.

6. Partisipasi merupakan cara yang paling efektif untuk mengembangkan kemampuan masyarakat untuk pengelolaan program pembangunan guna memenuhi kebutuhan.

7. Partisipasi bisa mencegah timbulnya pertentangan, konflik dan sikap-sikap yang tidak partisipatif.

8. Partisipasi bisa membangun rasa memiliki masyarakat terhadap agenda pemerintahan, kemasyarakatan dan pembangunan.

9. Partisipasi dipandang sebagai pencerminan demokrasi.

\section{Prinsip transparansi dalam penggunaan keuangan Alokasi Dana Desa}

Berdasarkan data penelitian yang diperoleh, baik melalui wawancara, pengamatan dan dokumentasi, maka dapat disimpulkan bahwa penggunaan keuangan Alokasi Dana Desa di Desa Karumbu Kecamatan Langgudu Kabupaten Bima, dapat disimpulkan telah dilaksanakan dengan prinsip pengelolaan keuangan yakni transparansi atau keterbukaan.

Transparansi berarti keterbukaan (opennsess) dalam memberikan informasi yang terkait dengan aktivitas pengelolaan seumberdaya publik kepada pihak-pihak yang membutuhkan informasi. Pengelola keuangan Alokasi Dana Desa berkewajiban memberikan informasi keuangan dan informasi lainya yang akan digunakan untuk pengambilan keputusan oleh pihak-pihak yang berkepentingan.

Transparansi pada akhirnya akan menciptakan horizontal accountability antara pengelola keuangan Alokasi Dana Desa dengan masyarakat sehingga tercipta pemerintahan daerah yang bersih, efektif, efisien, akuntabel dan responsif terhadap aspirasi dan kepentingan masyarakat. Transparansi adalah prinsip yang menjamain akses atau kebebasan bagi setiap orang untuk memperoleh informasi tentang penyelenggaraan pembangunan masyarakat, yakni informasi tentang kebijakan proses pembuatan dan pelaksanaanya serta hasilhasil yang dicapai. Transparansi adalah adanya kebijakan terbuka bagi pengawasan.

Makna dari transparansi dalam penyelenggaraan keuangan Alokasi Dana Desa dapat dilihat dalam dua hal yaitu; (1) salah satu wujud pertanggung jawaban pengelola keuangan Alokasi Dana Desa kepada masyarakat, dan (2) upaya peningkatan manajemen pengelolaan dan penyelenggaraan Alokasi Dana Desa yang baik dan mengurangi kesempatan praktek kolusi, korupsi dan nepotisme (KKN).

Transparansi pengelola keuangan Alokasi Dana Desa perlu ditingkatkan agar publik memahami situasi pengelola keuangan Alokasi Dana Desa sehingga mempermudah publik untuk berpartisipasi dalam penyelenggaraan pengelola keuangan Alokasi Dana Desa. Adapun upaya-upaya yang perlu dilakukan dalam meningkatkan transparansi pengelola keuangan Alokasi Dana Desa kepada publik antara lain: 1) Pendayagunaan berbagai jalur komunikasi baik langsung maupun tidak langsung melalui temu wicara maupun media cetak maupun elektronik. 2) Menyiapkan kebijakan yang jelas tentang cara mendapatkan informasi, bentuk informasi yang dapat diakses publik dan informasi yang bersifat rahasia. 3) Membuat prosedur pengaduan apabila informasi tidak sampai ke publik. 4) Membuat peraturan yang menjamin hak publik untuk mendapatkan informasi pengelola keuangan Alokasi Dana Desa, 
fasilitas data base dan sarana informasi dan komunikasi.

Keberhasilan transparansi pengelola keuangan Alokasi Dana Desa ditunjukkan oleh indikator sebagai berikut: 1) meningkatnya keyakinan dan kepercayaan masyarakat/publik kepada pengelola keuangan Alokasi Dana Desa bahwa pengelola keuangan Alokasi Dana Desa adalah bersih dan berwibawa. 2) Meningkatnya partisipasi masyarakat/publik dalam penyelenggaraan pengelola keuangan Alokasi Dana Desa. 3) Bertambahnya wawasan dan pengetahuan masyarakat/publik terhadap penyelenggaraan pengelola keuangan Alokasi Dana Desa. 4) Berkurangnya pelanggaran terhadap peraturan perundang-undangan yang berlaku.

\section{KESIMPULAN}

Berdasarkan hasil analisis dan pembahasan, maka kesimpulan yang dapat diungkapkan dalam penelitian ini yakni:

1. Berdasarkan keempat indikator kaitan dengan fokus prinsip partisipatif dalam pengelolaan Alokasi Dana Desa di Karumbu Kecamatan Langgudu Kabupaten Bima, baik sejak tahap perencanaan, pelaksanaan, penatausahaan, pelaporan dan pertanggugjawaban wajib melibatkan masyarakat, para pemangku kepentingan di desa serta masyarakat luas, utamanya kelompok marjinal sebagai penerima manfaat dari program/kegiatan pembangunan di desa, hasil pelaksanaannya sudah berjalan sesuai dengan aturan penggunaan Alokasi Dana Desa yakni Peraturan Menteri Dalam Negeri No. 113 Tahun 2014 Tentang Pengelolaan Keuangan Desa.

2. Berdasarkan keempat indikator kaitan dengan fokus prinsip transparansi penggunaan Alokasi Dana Desa di Karumbu Kecamatan Langgudu Kabupaten Bima, baik tersedianya informasi yang memadai pada setiap proses penyusunan dan pelaksanaan kebijakan penggunaan Alokasi Dana Desa, adanya akses pada informasi cukup mudah dijangkau, bebas diperoleh dan tepat waktu dalam penggunaan Alokasi Dana Desa, adanya peraturan yang menjamin hak untuk mendapatkan informasi tentang penggunaan Alokasi Dana Desa, tersedianya pusat informasi layanan pendidikan seperti media, papan pengumuman, dan lain-lain dalam penggunaan Alokasi Dana Desa, hasil pelaksanaannya sudah berjalan sesuai dengan aturan penggunaan Alokasi Dana Desa yakni Peraturan Menteri Dalam Negeri No. 113 Tahun 2014 Tentang Pengelolaan Keuangan Desa.

\section{DAFTAR PUSTAKA}

Arikunto, Suharsimi, 2000, Manajemen Penelitian, Cetakan Kelima, Rineka Cipta, Jakarta.

Awang, Azam. 2010. Implementasi Pemberdayaan Pemerintah Desa. Yogyakarta: Pustaka Pelajar.

Azwar, Saifuddin. 2011. Metode Penelitian. Yogyakarta: Pustaka Pelajar.

Bungin, Burhan, 2003, Metode Penelitian Kualitatif, Aktualisasi Metodologis Ke Arah Ragam Varian Kontemporer, Cetakan Kedua, RajaGrafindo Persada, Jakarta.

Creswell. 2008. Metode Penelitian. Jakarta. Sinar Jaya.

Danim, Sudarwan, 2002, Menjadi Peneliti Kualitatif, Cetakan I, Pustaka Setia, Bandung.

Djemari, Mardapi, 2004, Penelitian, Tes dan Pengukuran, Program Pascasarjana Universitas Negeri Yogyakarta, Yogyakarta.

Eko, Sutoro. 2007. Alokasi Dana Desa Cermin Komitmen Kabupaten/Kota pada Otonomi Desa. Yogyakarta: FPPD.

Fadhilah, Putra, 2003, Paradigma Kritis dalam Studi Kebijakan Publik dan Ruang Partisipasi dalam Proses Kebijakan Publik, Pustaka Pelajar Offset, Yogyakarta.

Faisal, Sanapiah, 1995, Pengantar Penelitian, Rajawali Pers, Jakarta.

Hadi, Sutrisno, 1984, Statistik II, Yayasan Penerbit Fakultas Psikologi UGM, Yogyakarta.

Haris, Syamsuddin, Dkk., 2002, Desentralisasi, Demokratisasi dan Akuntabilitas Pemerintah Daerah, 
Asosiasi Ilmu Politik Indonesia (AIPI), Jakarta.

Jalal, Fasli dan Dedi Supriadi (Editor), 2001, Reformasi Manajemen dalam Konteks Otonmi Daerah, Diterbitkan Atas Kerjsama Depdiknas, BappenasAdicita Karya Nusa, Yogyakarta.

Mahsun, Mohamad, 2006, Pengukuran Kinerja Sektor Publik, BPFE, Yogyakarta.

Miles, Matthew B dan A. Michael Huberman, 1992, Analisis Data Kualitatif, Cetakan Pertama, UI-Press, Jakarta.

Minarti, Sri. 2011. Managemen Bank: Mengelola Lembaga Keuangan Secara Mandiri. Jogjakarta: Ar-Ruzz

Mohammad, Ismail, dkk, 2004, Konsep dan Pengukuran Akuntabilitas, Universitas Trisakti, Jakarta

Moleong, Lexy J., 1999, Metodologi Penelitian Kualitatif, Cetakan Kesepuluh, Remaja Rosdakarya, Bandung.

Muhajir, Noeng, 1992, Metode Penelitian Kualitatif, Raka Sarasin, Yogyakarta.

Mulyasa, 2010, Manajemen Berbasis Bank. Bandung, Remaja Rosda Karya.

Muninjaya, A.A. Gde, 1999, Manajemen Kesehatan, Penerbit Buku Kedokteran Jakarta.

Mustopadidjaja. AR. 2003. Manajemen Proses Kebijakan Publik, Formulasi, Implementasi dan Evaluasi Kinerja. Perum Percetakan Negara RI. Jakarta.

Nazir, Moh., 1999, Metode Penelitian, Cetakan Keempat, Ghalia Indonesia, Jakarta. 